\title{
Combinational Drug Therapy and Electrolyte Disorder in a Hypertensive Patient-A Case Report
}

\author{
Poojitha Mandava*,Tunuguntla Kusuma Naga Venkata Raja Kiranmai, Pilli Sai Mounika, A.M.S \\ Sudhakar Babu
}

Department of Pharmacy Practice, A.M. Reddy Memorial College of Pharmacy, Narsaraopet, Guntur Dist., A.P, INDIA.

\begin{abstract}
Hyponatremia and Hypokalemia are Electrolyte Disorders which are less common but serious effects that lead to severe complications such as death. This usually occurs due to imbalance between water and electrolytes in body often presented with signs and symptoms of Vomiting, Diarrhea, and Generalised Weakness. The common causes include decreased intake, increased excretion of Sodium, Potassium and rarely Drug induced. Immediate correction of electrolytes is very crucial by stopping the causative agents and providing additional support. This is a Case Report presenting: A 72 year old male patient presented to the hospital with symptoms of Generalised weakness and with past history of hypertension and Diabetes and he is on regular medication. Laboratory investigations showed abnormal values of Serum \& Urinary Sodium and Potassium ions. On observing this case, it is found that it is the effect of ARB + Thiazide drug therapy and is managed by treating with additional supplements of Sodium [0.9\% Normal Saline] \& Potassium [Syrup Potassium Chloride] together with alteration of ARB + Thiazide therapy with "Loop Diuretics + Potassium Sparing Diuretics", which showed Good Results both by Physical response and Laboratory values.

Key words: Hyponatremia, Hypokalemia, ARB's, Thiazide drugs, Combinational Drug Therapy, Drug Induced Electrolyte Disorder.
\end{abstract}

\section{INTRODUCTION}

Hyponatremia is an electrolyte disorder in which the Serum Sodium Concentration is $<135 \mathrm{mmol} / \mathrm{L}$. This occurs due to the imbalance between the Body fluid and Electrolyte disorder. This condition causes medical emergency to patients and is also associated with morbidity and mortality. ${ }^{1}$ among the various aetiologies, the common causes of Hyponatremia includes: Decreased intake of Sodium, Inappropriate secretion of AntiDiuretic hormone, Treatment of Hypertension with ARB's and Diuretics.

Hypokalemia is also an electrolyte disorder where the serum potassium concentration $<3.5 \mathrm{mmol} / \mathrm{L}$.Various causes of Hypokalemia include: Decreased intake of Potassium, use of Diuretics as a treatment for Hypertension. Diuretics-induced- electrolyte disturbances is uncommon and occurs rarely, as a complication of diuretic therapy. ${ }^{2,3}$
Decrease in the Serum Sodium and Potassium levels and Increase in Urinary Sodium and Potassium levels indicates the electrolyte imbalance/disorders. Other signs and symptoms include-Vomiting, Diarrhea, Weakness, Irregular Heart Rhythm [due to abnormal contractility of Heart]. Management of Electrolyte imbalance is very essential, or else may result in various complications leading to Coma and death.

Angiotensin Receptor Blockers and Thiazide Diuretics given as a therapy for patients with Hypertension are well documented evidences with less incidence of causing Electrolyte disturbances.

This Case Report is an example of such Drug-Induced-Electrolyte Disorder, suggesting that Medical attention is necessary.

\section{CASE REPORT}

A 72-year-old Male patient with generalized weakness gradually progressive in
DOI: 10.5530/ijopp.9.4.10

Address for correspondence: Poojitha Mandava Student, Pharm. D- Intern, Department of Pharmacy Practice, A.M.Reddy Memorial College of Pharmacy, Narsaraopet, Guntur Dist., A.P, INDIA.

E-Mail: poojithamandava9@ gmail.com

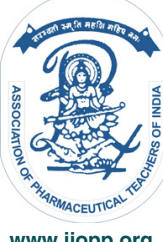


nature was admitted to a local hospital 2 months before. He had been diagnosed with Hypertension and diabetes 25 years, 18 years back. $\mathrm{He}$ is on medications with Telmisartan+Chlorthalidone $(40+6.25 \mathrm{mg}) \mathrm{OD}$, Glimepride+Metformin $(2+500 \mathrm{mg})$ OD, Clopidogrel +Aspirin+Atorvastatin $(75+75+10 \mathrm{mg})$ OD, Pantoprazole $40 \mathrm{mg}$ OD, Remylin-D OD, Levocetirizine OD.

\section{On admission, the patient's vital signs were:}

B.P-110/60 mmHg,

P.R- 90 beats/ min,

R.R- 20 breaths/min,

Temperature-Normal.

Physical Examination: -

CVS-S1S2+,

CNS- NAD,

RS- B/L AE+

The Laboratory Investigations include:

$\mathrm{Hb}-14 \mathrm{gm} / \mathrm{dl}$,

RBC- 6 million cells/cumm,

WBC- 7,540 cells/cumm,

Platelets- 2.6 lac cells/cumm,

ESR- $10 \mathrm{~mm} / \mathrm{hr}$,

$\mathrm{Na}+-110 \mathrm{mmol} / \mathrm{L}$,

$\mathrm{K}+-2.5 \mathrm{mmol} / \mathrm{L}$,

Creatinine- $1.0 \mathrm{mg} / \mathrm{dl}$,

Blood Urea- $20 \mathrm{mg} / \mathrm{dl}$,

RBS- $120 \mathrm{mg} / \mathrm{dl}$,

Total Cholesterol- $140 \mathrm{mg} / \mathrm{dl}$,

Triglycerides- $156 \mathrm{mg} / \mathrm{dl}$,

Urine Na+-30 mmol/L.

Thyroid Report Shows Normal Values.

The biochemistry reports showed the presence of Hyponatremia with $\mathrm{Na}+$ values of $110 \mathrm{mmol} / \mathrm{L}$; Hypokalemia with $\mathrm{K}+$ values of $2.5 \mathrm{mmol} / \mathrm{L}$ respectively. The high Urine sodium levels of $30 \mathrm{mmol} / \mathrm{L}$ showed the presence of sodium loss through urine. The absence of Vomiting, Diarrhea confirmed the Diagnosis as "DRUG- INDUCED- HYPONATREMIA, HYPOKALEMIA".

The initial treatment given to treat Hyponatremia includes- alteration of anti-hypertensive drug to Inj. Furosemide+ Spironolactone BD. Additional treatment includes- $0.9 \%$ Nacl IV infusion. For HypokalemiaSyrup Potassium Chloride $15 \mathrm{ml}$ TID was given. The patient's laboratory values of $\mathrm{Na}+\mathrm{K}+$ improved to 118 $\mathrm{mmol} / \mathrm{L}, 2.8 \mathrm{mmol} / \mathrm{L}$ on Day 2, and on Day 3 the val- ues were Na+- $125 \mathrm{mmol} / \mathrm{L}, \mathrm{K}+-3.0 \mathrm{mmol} / \mathrm{L}$. The Day 4 values were $\mathrm{Na+-} 130 \mathrm{mmol} / \mathrm{l}, \mathrm{K}+-3.3 \mathrm{mmol} / \mathrm{l}$. on Day 5 the values were Urinary $\mathrm{Na}+-20 \mathrm{mmol} / \mathrm{L}, \mathrm{Na+-}$ $136 \mathrm{mmol} / \mathrm{L}, \mathrm{K}+-3.5 \mathrm{mmol} / \mathrm{L}$.

The Blood Pressure of the patient was under control at $120 / 80 \mathrm{mmHg}, 130 / 80 \mathrm{mmHg}, 130 / 80 \mathrm{mmHg}$, and 130/90 mmHg. On Day $30.9 \% \mathrm{NaCl}$ was discontinued and only the alternative anti-hypertensive drug therapy was continued.

On Day 3 the patient condition was Stable and generalised weakness was improved. By Day 5 the Patient's Signs and Symptoms were improved. On Day 6 the patient was discharged.

\section{DISCUSSION}

Angiotensin Receptor Blockers act by blocking the binding of Angiotensin II to Angiotensin II receptor thereby decreasing the Vasoconstriction and Intracellular Volume. ${ }^{4}$ Thiazide Diuretics act by increasing Sodium excretion and water retention in the body. ${ }^{5}$ Thus, ARB along with Thiazide diuretics proves more effective in lowering Blood Pressure. ${ }^{6-8}$ The case report shows the adverse effect of Hyponatremia and Hypokalemia due to the drug agents Telmisartan+Chlorthalidone, with symptoms of weakness. Thus, continuous monitoring or time to time monitoring of Electrolytes is necessary in patients given with this combination therapy, along with patient education regarding the side effects and their management.

\section{CONCLUSION}

The possibility of Drug-induced electrolyte imbalance, which is due to the agents such as Telmisartan [ as a cause for Hyponatremia ] and Chlorthalidone [ as a cause for Hypokalemia ], and the condition is reversed and managed after the withdrawal of those agents from therapy along with additional support by $0.9 \%$ Normal Saline and Potassium Chloride syrup.

Thus, Medical attention/Monitoring is needed in patients given with such combination therapy for Hypertension.

\section{ACKNOWLEDGEMENT}

We are thankful to the Hospital Management, LSSSH Guntur, to our College Management ,AMRCP Narsaraopet.

\section{CONFLICT OF INTEREST}

The Authors have no Conflict of Interest. 


\section{ABBREVIATION USED}

ARB's: Angiotensin Receptor Blockers; OD: once a Day; BID: Twice a Day; TID: Thrice a Day; LSSH: Lalitha Super Specialty Hospital; AMRMCP: A.M.Reddy Memorial College of Pharmacy.

\section{REFERENCES}

1. Funk GC, Lindner G, Druml W et al. Incidence and prognosis of dysnatremias present on ICU admission. Intens Care Med.2010;36(2):304-11. http://dx.doi. org/10.1007/s00134-009-1692-0 ; PMid:19847398.

2. Ayus JC. Diuretic-induced Hyponatremia. Arch Intern Med. 1986;146:12956.http://dx.doi.org/10.1001/archinte.1986.00360240163030: http://dx.doi. org/10.1001/archinte.1986.00360190059004: http://dx.doi.org/10.1001/ archinte.146.7.1295; PMid:3718124.

3. Chow KM, Szeto CC, Wong TY, et al. Risk factors for thiazide-induced Hyponatremia. QJM. 2003;96(12):911-7. http://dx.doi.org/10.1093/qjmed/ hcg157 ; PMid:14631057.

4. Burnier M. Angiotensin II type 1 receptor blockers. Circulation. 2001;103(6):90412. http://dx.doi.org/10.1161/01.CIR.103.6.904 ; PMid:11171802.
5. Meredith PA. Angiotensin II receptor antagonists alone and combined with hydrochlorothiazide: potential benefits beyond the antihypertensive effect. Am J Cardiovasc Drugs.2005;5(3):171-83. http://dx.doi.org/10.2165/00129784200505030-00004 ; PMid:15901205.

6. Kjeldsen SE, Os I, Høieggen A, Beckey K,Gleim GW, Oparil S. Fixed-dose combinations in the management of hypertension: defining the place of angiotensin receptor antagonists and hydrochlorothiazide. Am J Cardiovasc Drugs.2005;5(1):17-22. http://dx.doi.org/10.2165/00129784-200505010-00003 ; PMid:15631534.

7. Manolis AJ, Grossman E, Jelakovic B, et al.: Effects of losartan and candesartan monotherapy and losartan/hydrochlorothiazide combination therapy in patients with mild to moderate hypertension. Losartan Trial Investigators. ClinTher.2000;22(10):1186-203. http://dx.doi.org/10.1016/ S0149-2918(00)83062-3.

8. Chrysant SG, Weber MA, Wang AC, Hinman DJ: Evaluation of antihypertensive therapy with the combination of olmesartan medoxomil and hydrochlorothiazide. Am J Hypertens.2004;17(3):252-9. http://dx.doi. org/10.1016/j.amjhyper.2003.11.003; PMid:15001200. 